\title{
Ants interacting with fruits of Melocactus conoideus Buining \& Brederoo (Cactaceae) in southwestern Bahia, Brazil
}

\author{
Katielle Silva Brito-Kateivas ${ }^{1,2 *}$ \\ Michele Martins Corrêa ${ }^{1,3}$ \\ ' Departamento de Estudos Básicos e Instrumentais, Universidade Estadual do Sudoeste da Bahia \\ Praça da Primavera 40, Bairro Primavera, CEP 45700-000, Itapetinga - BA, Brazil \\ ${ }^{2}$ PPG em Genética, Biodiversidade e Conservação \\ Universidade Estadual do Sudoeste da Bahia \\ ${ }^{3}$ Departamento de Ciências Naturais, Universidade Estadual do Sudoeste da Bahia \\ * Corresponding author \\ katielle_brito@yahoo.com.br
}

Submetido em 16/03/2011

Aceito para publicação em 27/04/2012

\section{Resumo}

Formigas que interagem com frutos de Melocactus conoideus Buining \& Brederoo (Cactaceae) no sudoeste da Bahia, Brasil. O objetivo deste estudo foi verificar quais espécies de formigas interagem com os frutos de Melocactus conoideus e se existe remoção. O estudo foi realizado no Parque Municipal Serra do Periperi, município de Vitória da Conquista, Bahia, área de ocorrência da espécie. Frutos de 30 indivíduos foram marcados e observados durante o dia para identificação do comportamento das formigas. Sete espécies de cinco subfamílias de formigas foram observadas interagindo com os frutos e os gêneros mais envolvidos em interações foram Camponotus e Pheidole. Três eventos de remoção foram observados e realizados apenas pela espécie Pheidole sp. 2. Apesar de M. conoideus não ser uma espécie mirmecocórica, formigas foram registradas como dispersoras oportunistas, atividade que pode ter importantes consequências para a dinâmica populacional da espécie.

Palavras-chave: Dispersão oportunista; Espécie ameaçada; Formicidae

\section{Abstract}

The aim of this study was to determine which ant species interact with the fruits of Melocactus conoideus and if there is removal. The study was carried out at Parque Municipal Serra do Periperi, in the town of Vitoria da Conquista, Bahia, Brazil, an area where the species occur. Fruits from 30 individuals were marked and observed during day for identification of the ants behavior. Seven species from five ant subfamilies were observed interacting with the fruits and the genera mostly involved in interactions were Camponotus and Pheidole. Three removal events were observed, performed by Pheidole sp. 2. Although M. conoideus is not a myrmecochorous species, ants were registered as opportunistic dispersing agents, an activity which may have important consequences for the population dynamics of the species.

Key words: Endangered species; Formicidae; Opportunistic dispersal 


\section{Introduction}

Seed dispersal is a key demographic process in plant life that links pollination to recruitment, leading to the establishment of adults (JORDANO et al., 2006). The most common type of seed removal in tropical forests is promoted by animals (JORDANO et al., 2006), and an important interaction in many ecosystems (HOWE; SMALLWOOD, 1982) is often performed by ants (MANZANEDA et al., 2005). The benefits of myrmecochory are determined by the specific conditions at the seed arrival site, usually in the nests, where the amounts of nitrogen, phosphorus and other nutrients are larger (CULVER; BEATTIE, 1978; BEATTIE, 1985; LEAL, 2003), which stimulates its germination (BOYD, 2001). Additionally, the removal of seeds away from parents, where predation and competition are lower, increase the recruitment success (HOWE; SMALLWOOD, 1982). Other benefits of myrmecochory are the fact that seeds deposited in nests may escape from fire (BEATTIE, 1985) and avoid predators, as some ants tend to be aggressive in the presence of other arthropods (ALMEIDA; FIGUEIREDO, 2003).

Dispersal by ants usually involves plants that produce elaiosomes, appendices consisting of lipid substances that are found in seeds of some plant families (BEATTIE, 1985). They are considered to be very important to the success of myrmecochory, as they serve as attractive elements due to their high energetic value (GORB; GORB, 1995). However, even non-myrmecochorous plants (without elaiosome) have their diaspores dispersed by ants (PIZO; OLIVEIRA, 1998; 2000; CHRISTIANINI et al., 2007, MUNGUÍAROSAS et al., 2009).

More than 3000 species and 80 families of angiosperms are described as true myrmecochorous (LEAL et al., 2007). One taxon with frequent records of seed dispersal by ants is Cactaceae (LEAL, 2003; LEAL et al., 2007; ROMÃO et al., 2007; MUNGUÍAROSAS et al., 2009). This family, composed of species with many different forms and abundant in arid and semiarid environments, has a high number of endangered species (GODÍNEZ-ÁLVAREZ et al., 2003), mainly due to excessive commercial exploit for ornamental purposes (ROJAS-ARÉCHIGA; VÁZQUEZ-YANES,
2000). Melocactus Link \& Otto is a homogeneous group of small globular cacti (RIZZINI, 1982) which is one of the most endangered ones in this taxon, with 11 species classified under some degree of risk for extinction by the CITES red list (TAYLOR; ZAPPI, 2004).

Melocactus conoideus Buinning \& Brederoo is an endemic species of a quartz gravel soil restricted to an area of only $10 \mathrm{~km}^{2}$ (TAYLOR; ZAPPI, 2004). During years, soil extraction for civil construction purposes decreased suitable habitats for the species establishment and removed individuals from the population. Since 1999, part of the population is protected by a municipal area, named Parque Municipal Serra do Periperi, but most individuals located out of the protected area are still exposed to human impact. The International Union for Conservation of Nature (2010) considered this cactus as critically endangered, once it is a species with low population density, restricted distribution, and poorly known biology. Among the few studies on the ecology of this species (MACHADO, 2004; CERQUEIRA-SILVA; SANTOS, 2007; 2008; REBOUÇAS; SANTOS, 2007), no survey addresses the seed dispersal process.

Ants are reported as opportunistic dispersers of Melocactus species (ROMÃO et al., 2007). Thus, the purpose of this study was to verify how ant species interact with the fruits of $M$. conoideus and if there are removal events. These data are important for understanding an aspect of the dynamics of seed dispersal of $M$. conoideus and they may provide information for the implementation of future management plans for conservation of the species.

\section{Material and Methods}

The study was carried out at Parque Municipal Serra do Periperi (1449'49'S and 40 50'0.3'O), which occupies 1,300ha of urban area in the town of Vitoria da Conquista, Bahia, Brazil, and it is intended to preserve remnants of original vegetation of the headwaters of Verruga River and the species M. conoideus, whose occurrence areas are considered priority ones for conservation. The climate is semi-humid to tropical semiarid, characterized by water deficit from June to October and a high level of rain from November to 
March (BRASIL, 1981). The soil is mainly composed of quartz sand (SÁ, 2008) and the vegetation is an ecotone between the Seasonal Forest and the Steppic Savannah (BRASIL, 1981).

The species $M$. conoideus has small fruits, with a length of 17.1 to $21.5 \mathrm{~mm}$ and highest and lowest widths between 6.3 to $7.5 \mathrm{~mm}$ and 3.1 to $4.0 \mathrm{~mm}$ (BRITO; SANTOS, 2007). Fruits production in the species occurs the year round with peaks on April (CERQUEIRASILVA; SANTOS, 2007).

Fruits of M. conoideus are succulent, red pink colored, and completely developed within the cephalium, a reproductive and specialized protective structure (FONSECA, 2004). When ripe, the fruits are exposed on the surface of cephalium, turning it apparent to dispersal agents (RIZZINI, 1982; TAYLOR, 1991). The fruits have small black seeds, which are probably dispersed by lizards and ants (TAYLOR, 1991; FONSECA, 2004).

To verify if ant species interacted with fruits of $M$. conoideus, thirty adult cacti of similar size, which were at least $10 \mathrm{~m}$ distant from each other, were selected. In each plant, two fruits still inserted in the cephalium were marked with odorless ink. Interactions between ants and fruits of $M$. conoideus were surveyed by two observers for three days from 8:00 a.m. to 5:00 p.m., on July and August 2009. Each observer surveyed a set of five plants per day, through focal observations of $15 \mathrm{~min}$. The consecutive observation of these five plants (totaling $75 \mathrm{~min}$ ) was followed by an interval of $40 \mathrm{~min}$, after which another observation session was started. At the end of the day, each plant was observed for $75 \mathrm{~min}$.

Having the methodology used by Passos and Ferreira (1996) as a basis, the following behavioral patterns were observed: 1) cut or chew the fruit; 2) examine the fruit; 3) remove the fruit; and 4) try to remove the fruit. Fruit removing ants were observed and the fruit dispersal distance and destination were recorded. Ants specimens observed interacting with the fruits were collected, identified, and deposited in the zoological collection of the Biossistematica Animal Laboratory of Universidade Estadual do Sudoeste da Bahia, in the town of Itapetinga, Bahia, Brazil. The collected data were analyzed descriptively and compared to similar studies in the literature.

\section{Results}

Seven species of five subfamilies of ants were observed interacting with the fruits of $M$. conoideus. These species represent a subset of the local ant fauna with diurnal activity (Table 1). The interactions only occurred with the fruits marked that fell from cephalium and were on the floor ( 23 out of 60 marked fruits), i.e., after autochory. The most representative subfamilies in the interactions were Myrmicinae (three species) and Formicinae (two species). The most common genera involved in interactions was Pheidole Westwood, 1839 (two species) and Camponotus Mayr 1861 (two species). Pheidole sp. 2 and Camponotus crassus presented the largest number of interactions with fruits, $40 \%$ and $35 \%$ out of 20 total interactions, respectively.

The interacting ant species showed different behaviors. Five species were observed examining fruits on the ground; three species ate parts of the pulp but did not remove the seeds (cut) and only one species removed the fruit. None of the species tried to remove the fruit. The most frequent behavior displayed by ants was to "examine" (e) with $60 \%$ of the records (Table 1).

TABLE 1: Records of ant species and their behavior of interaction with fruits of $M$. conoideus at Parque Municipal Serra do Periperi, Vitoria da Conquista, BA.

\begin{tabular}{|c|c|c|c|c|}
\hline \multirow[t]{2}{*}{ Subfamily } & \multirow[t]{2}{*}{ Ant species } & \multicolumn{3}{|c|}{$\begin{array}{c}\text { Number of } \\
\text { records } \\
\text { in each } \\
\text { behavior }\end{array}$} \\
\hline & & $\mathrm{E}$ & $\mathrm{C}$ & $\mathrm{R}$ \\
\hline Formicinae & $\begin{array}{l}\text { Camponotus rufipes } \\
\text { (Fabricius 1775) }\end{array}$ & 1 & 0 & 0 \\
\hline Formicinae & $\begin{array}{l}\text { Camponotus crassus } \\
\text { Mayr } 1862\end{array}$ & 7 & 0 & 0 \\
\hline Myrmicinae & Crematogaster sp. & 0 & 1 & 0 \\
\hline Myrmicinae & Pheidole sp. 1 & 0 & 1 & 0 \\
\hline Myrmicinae & Pheidole sp. 2 & 2 & 3 & 3 \\
\hline Ponerinae & Anochetus sp. & 1 & 0 & 0 \\
\hline \multirow[t]{2}{*}{ Pseudomyrmecinae } & Pseudomyrmex sp. & 1 & 0 & 0 \\
\hline & TOTAL & 12 & 5 & 3 \\
\hline
\end{tabular}

* E - examined; $\mathrm{C}$ - cut; $\mathrm{R}$ - removed. 
Only two species of the genus Pheidole and one of the genus Crematogaster showed a relevant behavior for seed dispersal of M. conoideus as cut and removal. The removal of fruits was carried out by one species of Pheidole, sp. 2, which removed 3 (13\%) out of 23 fallen fruits. After finding and examining the fruit on the ground below the parent plant, this species recruited other workers to assist in the removal. Removal distances were 15,40 , and $70 \mathrm{~cm}$. Only the removal event of $70 \mathrm{~cm}$ was from plant to nest, destination of the fruit (Figure 1). The other removed fruits were left close to the fruiting individual. This ant species was also observed trying to remove and removing other non-marked fruits, and also throwing apparently undamaged seeds in dumps at the nest entrances. The other Pheidole species and one Crematogaster species cut and chewed one fruit, releasing the seeds from the pulp.

FIGURE 1: Interaction between fruits of Melocactus conoideus Buin. \& Bred. (Cactaceae) and the ant species Pheidole sp. 2 at Parque Municipal Serra do Periperi, Vitoria da Conquista, southwestern Bahia. (A) Fruit of M. conoideus being carried by workers, (B) Measure of the fruit removal of $70 \mathrm{~cm}$ from the fruiting adult to the nest.

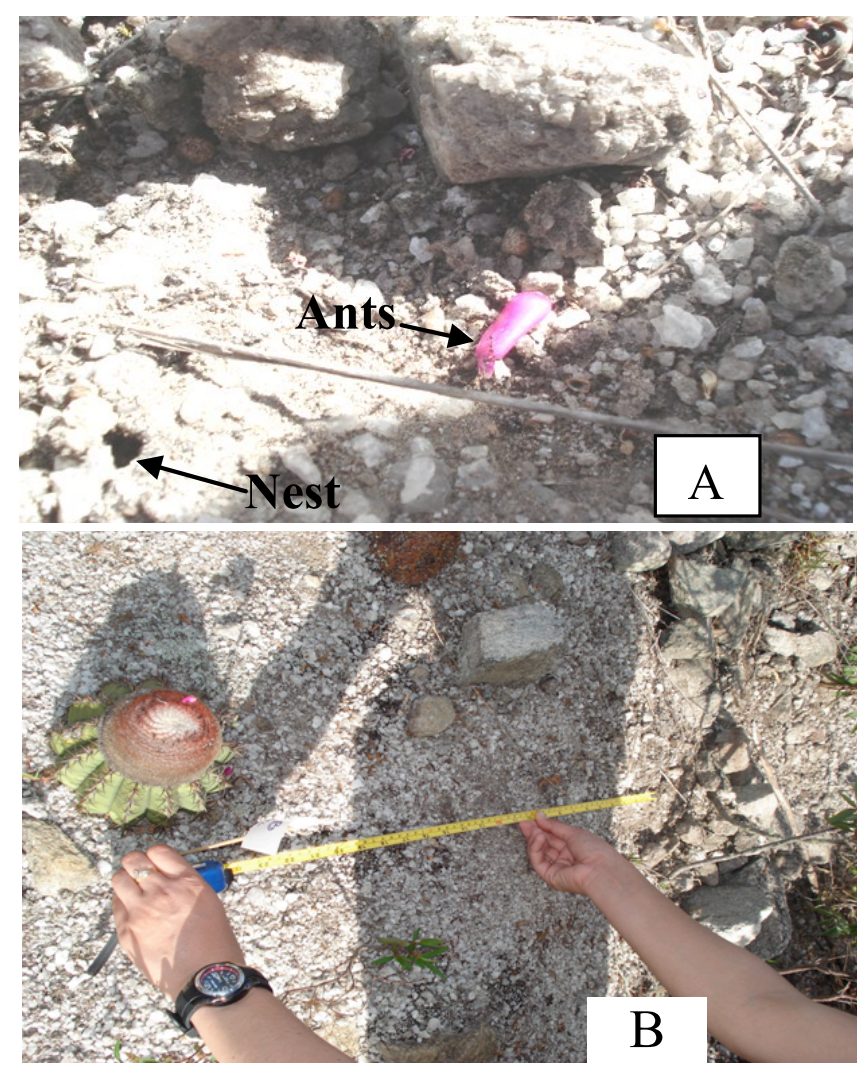

\section{Discussion}

Our results indicate that at least one ant species of diurnal activity (Pheidole sp. 2) acts as an opportunistic disperser of $M$. conoideus fruits in its range. The proportion of seed dispersal was low, comparing with the other observed interactions, and it occurred only at short distances. However, in the absence of the primary dispersers, probably lizards, as reported to Melocactus species according to Figueira et al. (1994) and Romão et al. (2007), the importance of ants as seed removers possibly increases.

After being expelled from the cephalium, the fruits remain closer to parent plant (about $0-10 \mathrm{~cm}$, pers. obs.) than the removal distance achieved by the ants. Two species were also registered cutting and chewing the fruits. This behavioral pattern of pulp removal could increase the chance of seed germination by decreasing the fungus attack (LEAL; OLIVEIRA, 1998; LEAL, 2003). Even a removal by a short distance, as performed by ants, also may be beneficial for the plant, because they change the dispersion arrangement carried out by primary dispersers, reduce competition and predation (HOWE; SMALLWOOD, 1982; BEATTIE, 1985; COSTA et al., 2007). In addition, one of the deposition sites of fruits was the nest, and according to Howe and Smallwood (1982) and Passos and Oliveira (2003), the soil of the ant nests is favorable for germination, growth and establishment of seedlings due to its higher concentration of nutrients (LEAL et al., 2007; RICOGRAY; OLIVEIRA, 2007) and greater soil penetration (see HOWE; SMALLWOOD, 1982). Thus, fruits removed by ants have a higher chance to find suitable habitats and survive than those which remain close the parent plant and may suffer from density effects.

The importance of Pheidole as seed dispersers of several plant species was often reported (LEAL, 2003; PETERNELLI et al., 2004; COSTA et al., 2007; LEAL et al., 2007) and it may reflect the biology of the taxon, as described by Wilson (1976). According to the author, Pheidole species show high diversity and many adaptations, wide geographic distribution, and local abundance, that made them widespread in global scale. Additionally, species from this genus can colonize 
disturbed environment (FONSECA; DIEHL, 2004), as found at the study area. All these characteristics may favor the interaction between Pheidole species and $M$. conoideus fruits once the fruit production is stable (CERQUEIRA-SILVA; SANTOS, 2007).

In general, different ants deal with diaspores in different ways, according to their genus and size (GORB; GORB, 1995; COSTA et al., 2007; RICOGRAY; OLIVEIRA, 2007). Due to the small body size, Pheidole species recruit other colony members for the collection or removal of the fruits (PIZO; OLIVEIRA, 2000; PASSOS, 2001; PASSOS; OLIVEIRA, 2003; PETERNELLI et al., 2004; LEAL et al., 2007), a behavior observed in our study, in which the fruits removal happened only after the recruitment of other ant workers.

Attracted by the aril or the fruit pulp (OLIVEIRA et al., 1999; RICO-GRAY; OLIVEIRA, 2007; MUNGUÍAROSAS et al., 2009), the ants are considered key dispersal agents for non-myrmecochorous species in many ecosystems (PIZO; OLIVEIRA, 1998; 2000; CHRISTIANINI et al., 2007; COSTA et al., 2007; RICO-GRAY; OLIVEIRA, 2007; MUNGUÍA-ROSAS et al., 2009). The role of ants as opportunistic dispersers observed in M. conoideus has already been recorded for other species of the genus by Taylor (1991), Figueira et al. (1994), Fonseca (2004), and Romão et al. (2007). This pattern is common in other species of the family Cactaceae (TAYLOR; ZAPPI, 2004) and where the preferential dispersers are less frequent (MONTIEL; MONTAÑA, 2000; MUNGUÍA-ROSAS et al., 2009) and it may influence the processes that shape the spatial distribution pattern of the species (GODÍNEZÁLVAREZ et al., 2003).

Our results report a preliminary aspect of the seed dispersal pattern of $M$. conoideus and the participation of ants in this process. Although the seed removal by ants was low and involved a short distance, ants probably increase the species survival as they rearrange the spatial distribution after being expulsed from the cephalium and probably after the primary dispersal. More studies are needed to determine the seed dispersal patterns of $M$. conoideus, as these data are essential for the construction of management plans that increase the survival viability of the species in its natural environment, which is very restricted and which has different frequencies and intensities of anthropic disturbances due to the extraction of gravel for urban building and expansion (TAYLOR; ZAPPI, 2004).

\section{Acknowledgements}

We thank the Environmental Authority of Vitoria da Conquista for allowing the studies at Parque Municipal Serra do Periperi and its staff for accompanying the visits. Additional thanks to Gabriela Vasconcelos de Oliveira for her help in the laboratory, Lucimeire RamosLacau for identifying the ants, R. J. de Sá-Neto for his contribution to the whole study, Ana Gabriela Bieber for helpful comments on the manuscript and Leonhard Krause for revising the English version.

\section{References}

ALMEIDA, A. M.; FIGUEIREDO, R. A. Ants visit nectaries of Epidendrum denticulatum (Orchidaceae) in a Brazilian rainforest: effects on herbivory and pollination. Brazilian Journal of Biology, São Carlos, v. 63, n. 4, p. 551-558, 2003.

BEATTIE, A. J. The evolutionary ecology of ant-plant mutualisms. Cambridge: Cambridge University Press, 1985. 182 p.

BOYD, R. S. Ecological benefits of myrmecochory for the endangered chaparral shrub Fremontodendron decumbers (Sterculiaceae). American Journal Botany, St. Louis, v. 88, n. 2, p. 234-241, 2001.

BRASIL-MINISTÉRIODASMINASEENERGIA/SECRETARIA GERAL. Salvador: geologia, geomorfologia, pedologia, vegetação e uso potencial da terra. Projeto RADAMBRASIL, Folha SD 24. Rio de Janeiro: Ministério de Minas e Energia/Secretária Geral (Levantamento de Recursos Naturais, 24), 1981. s/paginação.

BRITO, K. S.; SANTOS, D. L. Avaliação da qualidade fisiológica de sementes de Melocactus conoideus Buin. \& Bred. (Cactaceae) enterradas no solo durante um ano. In: REUNIÃO ANUAL DA SBPC, 59, 2007, Belém. Resumos... Belém: SBPC, 2007. Versão eletrônica.

CERQUEIRA-SILVA, C. B. M. C.; SANTOS, D. L. Fenologia reprodutiva de Melocactus conoideus (Buin. \& Bred) espécie endêmica do município de Vitória da Conquista, Bahia Brazil. Revista Brasileira de Biociências, Porto Alegre, v. 5, p. 1095 1097, 2007.

CERQUEIRA-SILVA, C. B. M.; SANTOS, D. L. "Estado da arte" do Melocactus conoideus: Uma espécie endêmica ameaçada de extinção. Boletín de la Sociedad Latinoamericana y del Caribe de Cactáceas y otras Suculentas, La Habana, v. 5, p. 12-16, 2008. Disponível em <http://scysnl.org/pdf/SLCCS_Sep-Dic2008.pdf>. Acesso em: 21 jan. 2009. 
CHRISTIANINI, A. V.; MAYHÉ-NUNES, A. J.; OLIVEIRA, P. S. The role of ants in the removal of non-myrmecochorous diaspores and seed germination in a Neotropical savanna. Journal of Tropical Ecology, Winchelsea, v. 23, p. 343-351, 2007.

COSTA, U. A. S.; OLIVEIRA, M.; TABARELLI, M.; LEAL, I. R. Dispersão de sementes por formigas em remanescentes de Floresta Atlântica nordestina. Revista Brasileira de Biociências, Porto Alegre, v. 5, p. 231-233, 2007.

CULVER, D. C.; BEATTIE, A. J. Myrmecochory in Viola: Dynamics of seed-ant interaction in some West Virginia species. Journal of Ecology, London, v. 66, p. 53-72, 1978.

FIGUEIRA, J. E. C.; VASCONCELOS-NETO, J.; GARCIA, M. A; SOUZA, A. L. T. Saurocory in Melocactus violaceus (Cactaceae). Biotropica, Maiden, v. 26, p. 295-301, 1994.

FONSECA, R. B. S. Fenologia reprodutiva e dispersão de Melocactus glaucescens Buining \& Brederoo e M. paucispinus G. Heiman \& R. Paul (Cactaceae) no município de Morro do Chapéu, Chapada Diamantina - Bahia - Brazil. 2004. 123 f. Dissertação (Mestrado em Botânica) - Universidade Estadual de Feira de Santana, Feira de Santana, 2004.

FONSECA, R.C. \& DIEHL, E. Riqueza de formigas (Hymenoptera, Formicidae) epigéicas em povoamentos de Eucalyptus spp. (Myrtaceae) de diferentes idades no Rio Grande do Sul, Brasil. Revista Brasileira de Entomologia, Curitiba, v.48, n.1, p.95-100, 2004.

GODÍNEZ-ÁLVAREZ, H.; VALVERDE, T.; ORTEGA-BAES, P. Demographic trends in the Cactaceae. The Botanical Review, New York, v. 69, n. 2, p. 173-203, 2003.

GORB, S. N; GORB, E. V. Removal rates of seeds of five myrmecorchory plants by ant Formica polyctena (Hymenoptera: Formicidae). Oikos, Copenhagen, v. 73, p. 367-374, 1995.

HOWE, H. F.; SMALLWOOD, J. Ecology of seed dispersal. Annual Review of Ecology and Systematics, Palo Alto, v. 13, p. 201-228, 1982.

INTERNATIONAL UNION FOR CONSERVATION OF NATURE. IUCN Red list of threatened species. Version 2010.4. 2010. Disponível em: <www.iucnredlist.org>. Acesso em: 27 jan. 2011.

JORDANO, P.; GALETTI, M.; PIZO, M. A.; SILVA, W. R. Ligando frugivoria e dispersão de sementes à biologia da conservação. In: DUARTE, C. F.; BERGALLO, H. G.; DOS SANTOS, M. A. (Ed.). Biologia da conservação: essências. São Paulo: Editorial Rima, 2006. p. 411-436.

LEAL, I. R. Dispersão de sementes por formigas na caatinga. In: LEAL, I. R.; TABARELLI, M.; DA SILVA, J. M. C. (Ed.). Ecologia e conservação da Caatinga. Recife: Editora Universitária da UFPE, 2003. p. 593-624.

LEAL, I. R.; OLIVEIRA, P. S. Interactions between fungusgrowing ants (Attini), fruits and seeds in cerrado vegetation in southeast Brazil. Biotropica, Maiden, v. 30, p. 170-178, 1998.

LEAL, I. R.; WIRTH, R.; TABARELLI, M. Seed dispersal by ants in the semiarid Caatinga of North-east Brazil. Annals of Botany, Oxford, v. 99, n. 5, p. 885-894, 2007.

MACHADO, M. The conservation of Melocactus conoideus Buin \& Bred. in Vitória da Conquista, Brazil. British Cactos and Succulent Journal, Essex, v. 22, n. 3, p 139-146, 2004.
MANZANEDA, A. J.; FEDRIANI, J. M.; REY, P. J. Adaptive advantages of myrmecochory: The predator-avoidance hypothesis tested over a wide geographic range. Ecography, Lund, v. 28, p. 583-592, 2005.

MONTIEL, S.; MONTAÑA, C. Vertebrate frugivory and seed dispersal of a Chihuahuan Desert cactus. Plant Ecology, Perth, v. 146, p. 221-229, 2000.

MUNGUÍA-ROSAS, M. A; JACOME-FLORES, M. E; SOSA, V., QUIROZ-CERON, M. L. Removal of Pilosocereus leucocephalus (Cactaceae, tribe Cereeae) seeds by ants and their potential role as primary seed dispersers. Journal of Arid Environments, London, v. 73, p. 578-581, 2009.

OLIVEIRA, P. S., RICO-GRAY, V.; DIAZ-CASTELAZO, C.; CASTILLO-GUEVARA, C. Interaction between ants, extrafloral nectaries and insect herbivores in Neotropical costal sand dunes: Herbivore deterrence by visiting ants increases fruit set in Opuntia stricta (Cactaceae). Functional Ecology, London, v. 13, p. 623$631,1999$.

PASSOS, L. C. Ecologia da interação entre formigas, frutos e sementes em solo de mata de restinga. 2001. 140 f. Tese (Doutorado em Biologia Vegetal) - Universidade Estadual de Campinas, Campinas, 2001

PASSOS, L.; FERREIRA, S. O. Ant dispersal of Croton priscus (Euphorbiaceae) seeds in a tropical semideciduous forest in southeastern Brazil. Biotropica, Maiden, v. 28, n. 4b, p. 697-700, 1996.

PASSOS, L.; OLIVEIRA, P. S. Interactions between ants, fruits, and seeds in a restinga forest in south-eastern Brazil. Journal of Tropical Ecology, Winchelsea, v. 19, p. 261-270, 2003.

PETERNELLI, E. F. de O.; DELLA LUCIA, M. C.; MARTINS, S. $\mathrm{V}$. Espécies de formigas que interagem com as sementes de Mabea fistulifera Mart. (Euphorbiaceae). Revista Árvore, Viçosa, v. 28, n. 5, p. 733-738, 2004.

PIZO, M. A.; OLIVEIRA P. S. Interaction between ants and seeds of a nonmyrmecochorous neotropical tree, Cabralea canjerana (Meliaceae), in the Atlantic forest of southeast Brazil. American Journal Botany, St Louis, v. 85, n. 5, p. 669-674, 1998.

PIZO, M. A.; OLIVEIRA, P. S. The use fruits and seeds by ants in the Atlantic Forest of southeast Brazil. Biotropica, Maiden, v. 32, n. 4b, p. 851-861, 2000.

REBOUÇAS, A. C. M. N.; SANTOS, D. L. Influência do fotoperíodo e qualidade de luz na germinação de sementes de Melocactus conoideus (Cactaceae). Revista Brasileira de Biociências, Porto Alegre, v. 5, p. 900-902, 2007.

RICO-GRAY, V.; OLIVEIRA, P. S. The ecology and evolution of ant-plant interactions. Chicago: The University of Chicago Press, 2007. $331 \mathrm{p}$.

RIZZINI, C. T. Melocactus no Brazil. Rio de Janeiro: Jardim Botânico do Rio de Janeiro, 1982. 114 p.

ROJAS-ARÉCHIGA, M.; VÁZQUEZ-YANES, C. Cactus seed germination: A review. Journal of Arid Environments, London, v. 44, p. 85-104, 2000.

ROMÃO, R. L.; HUGHES, F. M.; VIEIRA, A. M. C.; FONTES, E. C. Autoecologia de Cabeça-de-frade (Melocactus ernestii Vaupel) 
em duas áreas de afloramentos na Bahia. Revista Brasileira de Biociências, Porto Alegre, v. 5, supl. 1, p. 738-740, 2007.

SÁ, M. S. P. A representação e conservação do Parque Municipal da Serra do Periperi numa visão escolar de alunos da 4a série do ensino fundamental. 2008. $70 \mathrm{f}$. Monografia (Especialização em Educação Ambiental) - Unidade Baiana de Ensino, Pesquisa e Extensão, Vitória da Conquista, 2008.

TAYLOR, N. P. The genus Melocactus (Cactaceae) in Central and South America. Bradleya, Norwich, v. 9, p. 1-80, 1991.

TAYLOR, N.; ZAPPI, D. C. Cacti of eastern Brazil. London: Royal Botanic Gardens, 2004. 499 p.

WILSON, E. O. Which are the most prevalent ant genera? Studia Entomologica, v. 19, p. 187-200, 1976. 